AGRICULTURE AND BIOLOGY JOURNAL OF NORTH AMERICA

ISSN Print: 2151-7517, ISSN Online: 2151-7525, doi:10.5251/abjna.2013.4.1.19.22

(C) 2013, ScienceHu $\beta$, http://www.scihub.org/ABJNA

\title{
Effect of amending soil with different levels of poultry droppings on the performance of water melon (Citrullus lanatus) in southern savannah of Nigeria
}

\author{
${ }^{1}$ Jimin, A.A., ${ }^{2}$ U.S. Asema, ${ }^{3}$ D. D. Ortserga and ${ }^{4}$ S. O. Onuh \\ ${ }^{1}$ Department of Agricultural Production Technology, ${ }^{2}$ Department of Soil Science, ${ }^{3}$ Department of \\ Animal Husbandry, ${ }^{4}$ Department of Animal Production Technology, Akperan Orshi College of \\ Agriculture Yandev, P.M.B 181 Gboko Benue State NIGERIA
}

\begin{abstract}
Field experiments were conducted at two locations (Yandev and Makurdi, Benue State) in 2008 and 2009 to assess the effect of amending soil with different levels of poultry droppings on the performance of water melon (Citrullus lanatus). The work consisted of four levels of poultry manure (0, 2.5, 5.0 and 10.0 tonnes per hectare) laid out in Randomized Complete Block Design (RCBD) and replicated three times. Significant increases in length of tendrils (up to $42 \%$ at Yandev) were observed at $6 \mathrm{WAP}$ with $10 \mathrm{t} / \mathrm{ha}$ poultry droppings compared to $4 \mathrm{WAP}$. The number of fruits per treatment also increased significantly $(P<0.05)$ with manure rates resulting in 54 and 24\% increase over control at Yandev and Makurdi respectively. The yield, (weight of fruits/ ha) showed significant $(\mathrm{P}<0.05)$ increase of 36.6 and $133.9 \%$ over control in the $10 \mathrm{t} / \mathrm{ha}$ treatment at Makurdi and Yandev locations respectively. Only the number of days to fruiting was significantly $(\mathrm{P}<0.05)$ influenced by location.
\end{abstract}

Keywords: soil, poultary droppings, water melon

\section{INTRODUCTION}

Most soils of the tropics are often strongly weathered and inherently low in nutrient status (Obi and Ebo, 1995). Crop yields on these soils are low. The use of chemical fertilizers alone to sustain high crop yields has not been quite successful due to enhancement of soil acidity through the application of such acid forming fertilizers as sulphate of ammonia, urea and ammonium nitrate. A further limitation of mineral fertilizers is their scarcity, high costs and lack of soil testing procedures by crop growers thus necessitating alternative sources of nutrients that would be less damaging to the soils (Nottidge et al., 2005; Ayeni, 2010). Another major limitation to the soil fertility is weathering (Obi and Ekperigin, 2001). Consequently attention is now shifting towards the use of organic manures as soil amendments in crop production.

According to Olatunji et al. (2006), the application of organic manure had been found to have higher comparative economic advantage over the use of inorganic fertilizer. A study conducted by Nwajiuba and Akinsanmi (2002) in Southeastern Nigeria, showed that returns per ha were higher on farms where organic amendments were used. Therefore, replenishment of nutrients and improvement in quality of nutrient depleted could be achieved through the application of inorganic fertilizers, organic manures or a combination of both (Adeniyan and Ojeniyi, 2005). Reports by Maynard (1991) indicated that the yield of some crops fertilized with 50 t/ha poultry manure was equal or greater than those obtained with inorganic fertilizers. In Nigeria, some studies (Obi and Ebo, 1995; Nottidge et al., 2005) showed that animal and plant wastes improved the physical conditions and fertility of soils. According to Adeniyan and Ojeniyi (2005), animal manure contains most of the essential nutrients that are used by plants which include nitrogen $(\mathrm{N})$, phosphorous $(\mathrm{P})$, potassium $(\mathrm{K})$, calcium (Ca), magnesium (Mg), sulfur (S), manganese $(\mathrm{Mn})$, copper $(\mathrm{Cu})$, zinc $(\mathrm{Zn})$, chlorine $(\mathrm{Cl})$, boron $(\mathrm{B})$, iron $(\mathrm{Fe})$, and molybdenum (Mo). Using animal manure as a fertilizer for crops or trees may therefore provide a portion, or all, of the plant requirements (Chastain, et. al., 2001). However, more information is needed on the potential of different wastes as yield improvers in crops. Therefore, the effect of poultry droppings on water melon was studied during the late seasons of 2008 and 2009 at 2 locations (Yandev and Makurdi) in Benue State, Nigeria. This study was aimed at ascertaining the effect of amending soils with different levels of poultry manure on the performance of water melon. 


\section{MATERIALS AND METHODS}

Field experiments were conducted during the late cropping seasons of 2008 and 2009 at the Teaching and Research Farms of Akperan Orshi College of Agriculture, Yandev (Lat $7^{\circ} 23^{\prime}$ and Long. $8^{\circ} 37^{\prime} \mathrm{E}$ ) and the University of Agriculture, Makurdi (Lat $7^{\circ} 41^{\prime}$ and Long. $\left.8^{\circ} 37^{\prime} \mathrm{E}\right)$ to determine the effect of poultry manure on the performance of water melon. Both locations fall within the southern guinea savannah ecological zone of Nigeria. The soil in Makurdi was sandy loam while that of Yandev location was loamy sand. Both had low organic matter content and exchangeable bases (Table 1).

The experiment consisted of four levels of poultry manure $(0,2.5,5.0$ and $10.0 \mathrm{t} / \mathrm{ha})$ laid out Randomized Complete Block Design (RCBD) replicated three times. Each treatment was assigned a plot size of $36 \mathrm{~m}^{2}$. Water melon seeds were obtained from the National Horticultural Research Institute, Ibadan. Raw poultry manure was obtained from the Benue State Agricultural Development Company. The poultry manure was incubated for 21 days before their application.

Three seeds of water melon were planted per hole at a spacing of $75 \mathrm{~cm} \times 50 \mathrm{~cm}$ and thinned to one plant per stand, two weeks after planting. The poultry manure was manually applied two weeks before planting at the appropriate levels.

Soil samples were collected at $0-20 \mathrm{~cm}$ depth for physico-chemical analysis and the chemical analysis of the poultry manure was determined (Table 2).

The effect of the treatments was measured in respect to length of tendrils at 4 and 6 WAP, days to first flowering, days to $50 \%$ flowering, days to fruiting, number of fruits per plot, average weight of fruits (from 10 stands per plot) and weight of fruits per plot. The data collected were analyzed by analysis of variance (ANOVA). Significantly different means were separated using the Least Significant Difference (LSD) according to the procedures outlined by Steel and Torrie (1980).

\section{RESULTS AND DISCUSSION}

Table 1 show some physico-chemical properties of soils of the two sites (Yandev and Makurdi) prior to planting. The soils are moderately acidic with low nutrient content. The texture of both sites is sandy in nature.
No significant increases $(P>0.05)$ in the length of tendrils were obtained with increasing poultry manure levels at 4 WAP (Tables 3 and 4). At 6 WAP however, both locations produced significant increases in length of tendrils. The Yandev site produced an increase in the $10 \mathrm{t} /$ ha treatment of over $42 \%$ compared to the control. Increased nutrient availability due to the decomposition of the manure over time probably led to the increased growth of the crop.

Significant increases $(P<0.05)$ in days to $50 \%$ flowering were observed at Yandev. The higher levels of poultry manure significantly $(P<0.05)$ delayed days to $50 \%$ flowering stage. It does appear that the increased vegetative growth in these treatments also caused a delay in flowering. The number of fruits per treatment increased significantly $(P<0.05)$ with manure rates resulting in over $54 \%$ increase over the control at the Yandev location and $24 \%$ increase at the Makurdi location and this could be attributed to effective decomposition of poultry manure and their high application rates. This view is supported by Agbede and Ojeniyi (2009), who had earlier reported that increased rates of application of poultry manure increase plant yields by at least $39.5 \%$

The effect of treatment on weight of fruits/hectare was significant. The $10 \mathrm{t} /$ ha poultry droppings produced $5.23 \mathrm{t} / \mathrm{ha}$ and $6.97 \mathrm{t} / \mathrm{ha}$ fruits at Makurdi and Yandev respectively. These values indicate increase of over $36.6 \%$ and $133.9 \%$ over the control (Agbede and Ojeniyi 2009). The higher nutrient from this rate may be responsible for the trend. The low yield obtained from the control treatment might have resulted from a decrease in the nutrient status of soils that are highly weathered and low in organic matter (Table 1).

Table 5 summarizes the effect of location on the agronomic performance of water melon. Only the number of days to fruiting was significantly $(P<0.05)$ influenced by location, with the Makurdi performing better than Gboko. The delay in the number of days to fruiting could be attributed to the higher incidence of rainfall in the location. Rice et al. (1986) had reported that excessive rainfall and humidity affect flower and fruit production and encourage leaf diseases and fruit rot. 
Table 1: Physico-Chemical Properties of Soils of the Study Sites

\begin{tabular}{|c|c|c|c|c|c|c|c|c|c|c|c|}
\hline \multirow[t]{2}{*}{ Location } & \multirow{2}{*}{$\underset{\%}{\text { Avg. C }}$} & \multirow{2}{*}{$\begin{array}{c}\mathrm{pH} \\
\left(\mathrm{H}_{2} \mathrm{O}\right)\end{array}$} & \multirow{2}{*}{$\begin{array}{c}\text { Total N } \\
(\%)\end{array}$} & \multirow{2}{*}{$\begin{array}{l}\text { Av. P } \\
\text { ppm }\end{array}$} & K & $\mathrm{Ca}$ & $\mathbf{M g}$ & $\mathrm{Na}$ & \multirow{2}{*}{$\begin{array}{l}\text { Exch. } \\
\text { Acidity }\end{array}$} & \multirow[t]{2}{*}{ ECEC } & \multirow[t]{2}{*}{ Texture } \\
\hline & & & & & \multicolumn{4}{|c|}{ Meq/100 Soil } & & & \\
\hline Makurdi & 1.20 & 5.63 & 0.10 & 3.63 & 0.40 & 3.2 & 2.8 & 0.21 & 1.25 & 7.86 & Sandy Loam \\
\hline Yandev & 0.60 & 5.77 & 0.03 & 4.07 & 0.35 & 4.0 & 2.2 & 0.19 & 0.40 & 7.14 & Loamy Sand \\
\hline
\end{tabular}

Table 2: Proximate and Percentage Composition of Poultry Droppings Used in the Experiment

\begin{tabular}{|c|c|c|c|c|c|c|c|c|}
\hline DM & CP & CF & ASH & EE & NFE & $\%$ N & $\%$ P & $\%$ K \\
\hline 92 & 15.30 & 12.50 & 24.0 & 2.0 & 38.2 & 2.10 & 0.71 & 1.06 \\
\hline
\end{tabular}

$\begin{array}{lll}\mathrm{DM} & = & \text { Dry Matter } \\ \mathrm{CP} & = & \text { Crude Protein } \\ \mathrm{CF} & = & \text { Crude Fibre } \\ \mathrm{EE} & = & \text { Ether Extract } \\ \mathrm{NFE} & = & \text { Nitrogen Free Extract } \\ \% \mathrm{~N} & = & \text { Percentage Nitrogen } \\ \% \mathrm{P} & = & \text { Percentage Phosphorus } \\ \% \mathrm{~K} & = & \text { Percentage Potassium }\end{array}$

Table 3: Effect of Treatments on Yield and Yield Components of Water melon in Makurdi

\begin{tabular}{|c|c|c|c|c|c|c|c|c|}
\hline \multirow{2}{*}{$\begin{array}{c}\text { Treatments } \\
\text { (t/ha) }\end{array}$} & \multicolumn{2}{|c|}{ Length of Tendrils } & $\begin{array}{c}\text { Flowering } \\
\mathbf{5 0 \%}\end{array}$ & $\begin{array}{c}\text { No. of Days } \\
\text { to Fruiting } \\
\text { (DAS) }\end{array}$ & $\begin{array}{c}\text { No. of } \\
\text { Fruits/m }\end{array}$ & $\begin{array}{c}\text { Av. Wt of } \\
\text { Fruits } \\
\text { (kg) }\end{array}$ & $\begin{array}{c}\text { Wt of } \\
\text { Fruits per } \\
\text { Ha (t/ha) }\end{array}$ & $\begin{array}{c}\text { Av. Sugar } \\
\text { Content } \\
\text { (g/100g juice) }\end{array}$ \\
\hline 0 & 0.33 & 1.65 & 37.58 & 38.08 & 3.02 & 1.24 & 3.83 & 4.50 \\
\hline 2.5 & 0.34 & 1.74 & 37.83 & 38.50 & 3.75 & 1.32 & 4.13 & 5.44 \\
\hline 5.0 & 0.38 & 1.89 & 37.42 & 37.50 & 3.91 & 1.63 & 5.04 & 4.92 \\
\hline 10.0 & 0.36 & 1.94 & 38.01 & 38.47 & 3.98 & 1.66 & 5.23 & 4.86 \\
\hline LSD (5\%) & NS & 0.12 & NS & NS & 0.14 & NS & 0.36 & 0.60 \\
\hline
\end{tabular}

Table 4: Effect of Treatments on Yield and Yield Components of Water melon at Yandev

\begin{tabular}{|c|c|c|c|c|c|c|c|c|}
\hline \multirow{2}{*}{$\begin{array}{l}\text { Treatments } \\
\text { (t/ha) }\end{array}$} & \multicolumn{2}{|c|}{ Length of Tendrils } & \multirow{2}{*}{$\begin{array}{c}\text { Flowering } \\
50 \%\end{array}$} & \multirow{2}{*}{$\begin{array}{l}\text { No. of Days } \\
\text { to Fruiting } \\
\text { (DAS) }\end{array}$} & \multirow{2}{*}{$\begin{array}{c}\text { No. of } \\
\text { Fruits } / \mathrm{m}^{2}\end{array}$} & \multirow{2}{*}{$\begin{array}{l}\text { Av. Wt of } \\
\text { Fruits } \\
\text { (kg) }\end{array}$} & \multirow{2}{*}{$\begin{array}{l}\text { Wt of } \\
\text { Fruits per } \\
\mathrm{Ha}(\mathrm{t} / \mathrm{ha})\end{array}$} & \multirow{2}{*}{$\begin{array}{c}\text { Av. Sugar } \\
\text { Content } \\
\text { (g/100g juice) }\end{array}$} \\
\hline & 4 WAP & 6 WAP & & & & & & \\
\hline 0 & 0.33 & 1.58 & 35.33 & 35.94 & 3.11 & 1.15 & $2.98^{\mathrm{a}}$ & 5.31 \\
\hline 2.5 & 0.34 & 1.91 & 36.56 & 37.06 & 3.67 & 1.20 & $3.67^{\circ}$ & 5.35 \\
\hline 5.0 & 0.35 & 1.98 & 42.39 & 41.78 & 4.89 & 1.68 & $6.85^{\mathrm{C}}$ & 5.89 \\
\hline 10.0 & 0.33 & 2.25 & 43.17 & 41.94 & 4.79 & 1.70 & $6.97^{\mathrm{C}}$ & 5.67 \\
\hline LSD (5\%) & NS & 0.26 & 3.04 & NS & 0.48 & NS & 0.66 & NS \\
\hline
\end{tabular}


Agric. Biol. J. N. Am., 2013, 4(1): 19-22

Table 5: Effect of Location on Agronomic Performance of Water melon under Later Season Conditions at Makurdi and Yandev Location

\begin{tabular}{|c|c|c|c|}
\hline \multirow[t]{2}{*}{ Agronomic Traits } & \multicolumn{2}{|c|}{ Location } & \multirow[t]{2}{*}{ LSD (0.5) } \\
\hline & Makurdi & Yandev & \\
\hline Length of tendrils at 4 WAP (m) & 0.32 & 0.38 & $0.10^{\mathrm{NS}}$ \\
\hline Length of tendrils at 6 WAP (m) & 1.83 & 1.77 & $0.06^{\mathrm{NS}}$ \\
\hline Days to flowering & 33.89 & 33.44 & $0.43^{\mathrm{NS}}$ \\
\hline Days to $50 \%$ flowering & 37.58 & 37.64 & $1.58^{\mathrm{NS}}$ \\
\hline Days to fruiting & 37.36 & 38.69 & $0.55^{\star}$ \\
\hline Number of fruits per plot & 3.69 & 3.72 & $1.80^{\mathrm{NS}}$ \\
\hline Weight of individual fruits per plot $(\mathrm{kg})$ & 1.41 & 1.38 & $1.80^{\mathrm{NS}}$ \\
\hline Weight of fruits per plot $(\mathrm{kg})$ & 3.85 & 4.17 & $0.51^{\mathrm{NS}}$ \\
\hline Average sugar content (g/100g juice) & 4.98 & 4.93 & 0.53 \\
\hline
\end{tabular}

* $\quad=$ Means significantly different $(\mathrm{P}<0.05)$.

NS $\quad=$ Means not significantly different $(P>0.05)$.

WAP $\quad=$ Weeks after planting.

\section{RECOMMENDATIONS}

On the basis of the results of this study, it may be recommended that progressive application of poultry droppings enhances the agronomic performance of water melon.

\section{REFERENCES}

Adeniyan, O. N and Ojeniyi, S. O. (2005). Effect of poultry manure and NPK 15-15-15 and combination of their reduced levels on maize growth and soil chemical properties. Nig. J. Soil Sci., 15: 34-41.

Ayeni, L.S (2010). Integrated plant management: A panacea for sustainable crop production in Nigeria. Int. J. Soil Sci., 6; $19-24$.

Chastain, J. P., Camberato, J. J and Albrecht, J. E. (2001). Nutrient content of livestock and poultry manure. http.www.clemson.edu/calfs/departments/biosystemse ng/faculty_staff/research/ accessed 7/21/2011.

Maynard, A.A. (1991). Intensive vegetable production using composted animal manure. Bull. Connecticut. Agric. Expt. Sta., 89; $13-16$.

Nwajiuba, C and Akinsanmi, A. (2002). Organic manure use among smallholders in the rainforest of South eastern Nigeria. Online- http.www.tropentag.de/2002/proceeding/node 188.html. accessed 7/21/2011.

Nottidge, D.O., Ojeniyi, S.O and Aswalam, D.O. (2005). Effect of plant residue and N.P.K fertilizer on nutrient status and yield of maize in humid ultisol. Nig. J. Soil Sci., $15 ; 1-8$.

Obi, M.E and Ebo, P.O. (1995). Effect of organic and inorganic amendments on soil physical properties and maize production on a severely degraded sandy soil in Southern Nigeria. Bioresources Tech., 5; 117 - 123.

Obi, O and Ekperigin, J. (2001). Effect of wastes and soil $\mathrm{pH}$ on growth and grain yield of crops. African Soils, $32 ; 3-15$.

Olatunji O., Ayuba, S. A and Oboh, V. U. (2006). Growth and yield of okra and tomato as affected by pig dung and other organic manures: Issues for economic consideration in Benue State. Proceedings of the 30th Annual Conference of the Soil Science Society of Nigeria, 5th - 9th December, 2006, held at University of Agriculture, Makurdi, pp. 91- 98.

Rice, R.P., Rice, L.W and Tindall, H.D. (1986). Fruit and vegetable production in Africa. Macmillan, London.

Steel, R.G.D and Torrie, J. H. (1980). Principles and Procedures of Statistics: A Biometric Approach. $3^{\text {rd }}$ ed. McGraw Hill Int. Co. 